\title{
Antimicrobial and antioxidant activity of essential oil and different plant extracts of Psidium cattleianum Sabine
}

\author{
M. C. Scur ${ }^{a *}$, F. G. S. Pinto ${ }^{a}$, J. A. Pandini ${ }^{a}$, W. F. Costa ${ }^{b}$, C. W. Leite ${ }^{b}$ and L. G. Temponi \\ aPrograma de Conservação e Manejo de Recursos Naturais, Laboratório de Biotecnologia, Universidade Estadual \\ do Oeste do Paraná - UNIOESTE, CEP 85819-110, Cascavel, PR, Brazil \\ ${ }^{\text {b}}$ Departamento de Química, Universidade Estadual de Maringá - UEM, CEP 87020-900, Maringá, PR, Brazil \\ 'Programa de Conservação e Manejo de Recursos Naturais, Laboratório de Botânica, Universidade Estadual do \\ Oeste do Paraná - UNIOESTE, CEP 85819-110, Cascavel, PR, Brazil \\ *e-mail: mayarascur@hotmail.com
}

Received: July 21, 2014 - Accepted: December 2, 2014 - Distributed: February 29, 2016

\begin{abstract}
The goals of the study were to determine: the antimicrobial and antioxidant activities of essential oil and plant extracts aqueous and ethanolic of Psidium cattleianum Sabine; the chemical composition of the essential oil of P. cattleianum; and the phytochemical screening of aqueous and ethanolic extracts of the same plant. Regarding the antimicrobial activity, the ethanolic extract exhibited moderate antimicrobial activity with respect to bacteria K. pneumoniae and S. epidermidis, whereas, regarding other microorganisms, it showed activity considered weak. The aqueous extract and the essential oil showed activity considered weak, although they inhibited the growth of microorganisms. About the antioxidant potential, the ethanolic and aqueous extracts exhibited a scavenging index exceeding $90 \%$, while the essential oil didn't show significant antioxidant activity. Regarding the phytochemical composition, the largest class of volatile compounds identified in the essential oil of $P$. cattleianum included the following terpenic hydrocarbons: $\alpha$-copaene (22\%); eucalyptol (15\%), $\delta$-cadinene $(9.63 \%)$ and $\alpha$-selinene $(6.5 \%)$. The phytochemical screening of extracts showed the presence of tannins, flavonoids, and triterpenoids for aqueous and ethanolic extracts. The extracts and essential oils inhibit the growth of microrganisms and plant extracts showed significant antioxidant activity. Also, the phytochemical characterization of the essential oil showed the presence of compounds interest commercial, as well as extracts showed the presence of important classes and compounds with biological activities.
\end{abstract}

Keywords: Psidium cattleianum, antimicrobial action, microdilution, GC-MS, antioxidant activity.

\section{Atividade antimicrobiana e antioxidante do óleo essencial e diferentes extratos vegetais de Psidium cattleianum Sabine}

\section{Resumo}

Os objetivos do trabalho foram determinar: as atividades antimicrobiana e antioxidante do óleo essencial e dos extratos vegetais aquoso e etanólico de Psidium cattleianum Sabine; a composição química do óleo essencial P. cattleianum e a triagem fitoquímica dos extratos vegetais aquoso e etanólico da mesma planta. Quanto à atividade antimicrobiana, o extrato etanólico apresentou atividade antimicrobiana moderada frente as bactérias K. pneumonieae e S. epidermidis, enquanto frente aos demais micro-organismos apresentou atividade considerada fraca. $\mathrm{O}$ extrato aquoso e o óleo essencial apresentaram atividade considerada fraca, embora tenham inibido o crescimento dos micro-organismos. Em relação ao potencial antioxidante, os extratos etanólico e aquoso apresentaram índice de sequestro superior a 90\%, enquanto o óleo essencial não apresentou atividade antioxidante significativa. Para a composição fitoquímica, a maior classe de compostos voláteis identificados no óleo essencial de $P$. cattleianum foram os hidrocarbonetos terpênicos, sendo eles: $\alpha$-copaeno (22\%), eucaliptol (15\%), $\delta$-cadineno $(9,63 \%)$ e $\alpha$-selineno $(6,5 \%)$. Na triagem fitoquímica dos extratos verificou-se a presença de taninos, flavonóides e triterpenóides tanto para o extrato aquoso quanto etanólico. Os extratos e óleo essencial inibiram o crescimento dos micro-organismos e os extratos vegetais apresentaram atividade antioxidante significativa. Também, a caracterização fitoquímica do óleo essencial mostrou a presença de compostos de interesse comercial, assim como os extratos apresentaram a presença de classes e compostos com importantes atividades biológicas.

Palavras-chave: Psidium cattleianum, ação antimicrobiana, microdiluição, CG/MS, atividade antioxidante. 


\section{Introduction}

The search for natural origin products with pharmacological properties has significantly contributed to the discovery of new substances that have important uses (Viegas Junior et al., 2006). In this sense, Brazil stands out as a potential source of these natural products for having the largest plant biodiversity on the planet and also because most of its plants are unexplored relative to their pharmacological potential (Pinto et al., 2002).

The inadequate and indiscriminate use of synthetic antimicrobials is leading to the selection of multi-resistant strains, the antimicrobial potential of plant extracts and essential oils are intended to delay this process through the emergence of new antimicrobial substances (Weber et al., 2014). In addition to the antimicrobial potential, the fact that some synthetic antioxidants widely used in the food industry can lead to the development of tumor cells has led to increase the demand for similar products of natural origin, among which essential oils and plant extracts that have phenolic compounds in their composition stand out for their important antioxidant activity (Sacchetti et al., 2005).

In the middle of the many families of plants investigated, the Myrtaceae family deserves some special interest. This family consists of approximately 3,800 species and 130 genera distributed worldwide (Lucas et al., 2005). In Brazil, this family is represented by about 1,000 species and 26 genera (Sobral et al., 2010), including many which are used owing their medicinal properties and importance as food sources (Agra et al., 2008). The genus Psidium has approximately 92 species distributed from Mexico to Uruguay and northern Argentina. In Brazil, it occurs from the Amazon region to the State of Rio Grande do Sul (Landrum, 2003). Among the species of the genus Psidium, Psidium cattleianum Sabine, popularly known as "strawberry guava" stands out for the commercial importance attributed to its fruit used in the food industry (Santos et al., 2007). However, although there are studies on the quality of their seeds (Silva et al., 2011), the antioxidant and antimicrobial activity of extracts obtained from its fruit (Medina et al., 2011), the chemical characteristics of its juice (Santos et al., 2007), and the chemical composition of the essential oil (Marques et al., 2008), there aren't reports about the phytochemical composition and their biological activities. The present study is the first record on the subject.

Based on the above, the goals of the present study were: to assess the antimicrobial potential of essential oil and plant extracts of $P$. cattleianum against gram-positive bacteria, gram-negative bacteria, and yeast; to evaluate the antioxidant activity of essential oils and plant extracts; and to determine the chemical composition of the essential oil and perform the phytochemical screening of the plant extracts.

\section{Material and Methods}

\subsection{Plant material}

The leaves of P. cattleianum were collected at the State University of West Paraná, Brazil (Latitude 24571 S; Longitude $53^{\circ} 281 \mathrm{~W}$ ) from January to April of 2013. A plant material sample was sent, identified, and incorporated into the Herbarium of the State University of West Paraná (UNOP), under the voucher number: 1323, SCUR, M. C.

The leaves collected were stored in an oven with air circulation at $40^{\circ} \mathrm{C}$, until they were dried and ground in a cutting mill with particle size less than $0.42 \mathrm{~mm}$. The dry extract was stored protected from light up to its use for the production of extracts or essential oil extraction.

\subsection{Obtaining extract}

The aqueous and the ethanolic extracts was obtained by the methodology describe by Ceyhan et al. (2012).

First, were added $20 \mathrm{~g}$ of the plant material in $100 \mathrm{~L}$ of distilled water and kept in a rotary shaker at $220 \times \mathrm{g}$ for 24 . After the time, the material was filtered and centrifuged at $5000 \mathrm{x} \mathrm{g}$ for $15 \mathrm{~min}$. The supernatant was collected and the aqueous extracts were stored at $4^{\circ} \mathrm{C}$ until use. The ethanolic extract was submitted to roto-evaporation in order to remove the solvent.

\subsection{Phytochemical screening of plant extracts}

The main secondary metabolites were detected using the method developed by Simões et al. (2005) assessing the presence of the following compounds classes: pyrogalic tannins; alkaloids; coumarins; saponins; anthocyanins; flavonoids; triterpenoids; and steroids.

\subsection{Essential oil extraction}

The essential oil was obtained according to the methodology of Weber et al. (2014). $70 \mathrm{~g}$ of fresh leaves of $P$. cattleianum were add in $600 \mathrm{~mL}$ distilled water and submitted to standard water steam dragging methodology for three hours using Clevenger-type equipment. The oil was stored at $4^{\circ} \mathrm{C}$ until use.

\subsection{Analysis of the chemical composition of the essential oil}

The chemical composition of the essential oil of P. catteianum was determined by gas chromatography-mass spectometry (GC-MS), the determination of its Kovats retention indexes $(\mathrm{KI})$, and the comparison with the literature using the studies conducted by Biegelmeyer et al. (2011).

\subsection{Microorganisms}

Microorganisms were used to determine the antimicrobial potential of the essential oil and the plant extracts of $P$. cattleianum, they were: five gram-negative bacteria: Pseudomonas aeruginosa ATCC 27853; Salmonella Enteritidis ATCC 14028; Proteus mirabilis ATCC 25933; Klebsiella pneumoniae ATCC 13883; and Escherichia coli ATCC 25922; four gram-positive bacteria: Enterococcus faecalis ATCC 19433; Staphylococcus epidermidis ATCC 12228; Staphylococcus aureus ATCC 25923; and Bacillus subtillis CCCD-B005; and yeast Candida albicans ATCC 10231.

Microorganisms previously kept at $-20^{\circ} \mathrm{C}$ were recovered in an enriched brain heart infusion (BHI) medium and incubated at $36^{\circ} \mathrm{C}$ for 24 hours. After this period, they were resuspended in $0.9 \%$ sterile saline solution to obtain the 
standard inoculum at a concentration of $1 \times 10^{8} \mathrm{UFC} / \mathrm{mL}$ according to MacFarland scale. Subsequently, dilutions were performed in $0.9 \%$ sterile saline solution in order to obtain a final inoculum at a concentrqation of $1 \times 10^{5} \mathrm{UFC} / \mathrm{mL}$, with the exception of $C$. albicans which was used at a final concentration of $1 \times 10^{6} \mathrm{UFC} / \mathrm{mL}$.

\subsection{Antimicrobial activity}

The antimicrobial activity of essential oil and extracts was determined using the broth microdilution method proposed by Sartoratto et al. (2004), and plant extract by Ayres et al. (2008).

\subsubsection{Plant extracts}

$10 \mu$ LAliquots of the microorganism's dilutions were distributed in 96-well microdilution plates containing $150 \mu 1$ of Mueller-Hinton broth, with the previous addition of extracts. The extracts were diluted in concentrations between 200 and $0.04 \mathrm{mg} / \mathrm{mL}$. The plates were incubated at $36^{\circ} \mathrm{C}$ for $24 \mathrm{~h}$. After, each plate received an aliquot of $10 \mu \mathrm{l}$ of $0.5 \%$ triphenyl tetrazolium chloride (TTC) and incubated for three more hours. The MIC was defined as the lowest concentration of extract that was able to prevent microbial growth (showed by the absence of red color).

\subsubsection{Essential oil}

$200 \mu \mathrm{L}$ of the essential oil of $P$. cattleianum at a concentration of $200 \mathrm{mg} / \mathrm{mL}$ previously diluted in Mueller-Hinton and methanol were added in 96-well microdilution plates, and after were made successive dilutions, obtaining concentrations between 200 to $0.04 \mathrm{mg} / \mathrm{mL}$. $10 \mathrm{uL}$ Aliquots of the microorganism's dilution were distributed in each well. The following steps was the same of the plant extracts.

\subsection{Determination of the minimum bactericidal and fungicidal concentrations}

The minimum bactericidal concentration $(\mathrm{MBC})$ and the minimum fungicidal concentration (MFC) were determined using the method described by Santurio et al. (2007).

From the wells in which there was no visible bacterial growth in the MIC test, prior to the addition of TTC, we withdrew an aliquot of $10 \mu \mathrm{l}$ and inoculated it on the Mueller-Hinton agar surface. The plates were incubated for $24 \mathrm{~h}$ at $36^{\circ} \mathrm{C}$ and, after this procedure, the $\mathrm{MBC}$ was defined as the lowest concentration of the extract/oil able to cause the death of the inoculum.

The tests of MIC and MBC were carried out in triplicate, and distilled water and ethanol was worn as the negative control and gentamicin was used as positive control for bacteria and nystatin was utilized for C. albicans.

\subsection{Antioxidant activity}

The assessment of the antioxidant activity using the DPPH (2.2-diphenyl-1-picrylhydrazyl) free radical method was evaluated as described by Scherer and Godoy (2009). For the analysis, $0.1 \mathrm{~mL}$ of each dilution samples were placed in test tubes containing $3.9 \mathrm{~mL}$ of the DPPH free radical $(0.2 \mathrm{mM})$ and homogenized. For the negative control, were used $0.1 \mathrm{~mL}$ of the control solution (methyl alcohol, acetone and water) with $3.9 \mathrm{~mL}$ of the DPPH radical. The commercial synthetic antioxidant butylated hydroxytoluene (BHT) was used for positive control, by the same procedure utilized for the negative control. The absorbance at $515 \mathrm{~nm}$ was measured using a spectrophotometer and monitored every 20 minutes until the values of samples were stabilized. The tests were carried out in triplicate.

The DPPH index was calculated using the antioxidant activity equation $(\%)=[(\mathrm{Abs} 0-\mathrm{Abs} 1) / \mathrm{Abs} 0] \times 100$, where Abs0 is the absorbance of the whitening agent and Abs 1 the absorbance of the sample.

The concentrations of the samples responsible for $50 \%$ of decrease of the initial activity of DPPH free radical (IC50) was calculated through linear regression.

\subsection{Statistical analysis}

The data obtained by calculating the DPPH and $\mathrm{EC}_{50}$ index were analyzed by Tukey's test with $5 \%$ significance using the Sisvar software (Ferreira, 2007).

\section{Results and Discussion}

The tests conducted for characterization and phytochemical screening of ethanolic and aqueous extracts of $P$. cattleianum revealed the presence of the same classes of metabolites, namely: tannins, flavonoids, and triterpenoids.

Couto et al. (2009) conducted studies on Myrtaceae family members and observed the presence the same classes of secondary metabolites in leaves of Psidium guineense, Pimenta pseudocaryophyllus, Eugenia uniflora, and Eugenia dysenterica, respectively, corroborating the findings of the present study.

With respect to the biological potential attributed to the classes of metabolites found in the present study, it is known that the use of medicinal plants containing flavonoids is vast and, although some studies have shown that certain flavonoids may have mutagenic effect, in general, they are considered beneficial, being used for their antitumor, antiviral, antihemorrhagic, hormonal, antiinflammatory, antimicrobial, and antioxidant properties (Simões et al., 2005). Plants rich in tannins are known for their antihemorrhagic, healing, and antiinflammatory properties and in the treatment of diarrhea, hypertension, rheumatism, gastritis, ulcers, and kidney disorders (Dufresne and Farnworth, 2001). Finally, the triterpenoids are known for their antihyperalgesic, antiinflammatory, and antimicrobial activities (Tepe et al., 2004).

With respect to the application of GC-MS, a total of 49 compounds were identified. The largest class of volatile compounds recognized in the essential oil of P. cattleianum belongs to terpenic hydrocarbons, represented by $\alpha$-copaene, which constituted approximately $22 \%$ the total area of the chromatogram peaks, followed by eucalyptol, (15\%), $\alpha$-cadinene (10\%), and $\delta$-selinene (6.42) (Table 1). The remaining compounds found showed peak areas of less than $4 \%$. 
Table 1. Chemical composition of the essential oil of Prunus myrtifolia.

\begin{tabular}{|c|c|c|c|}
\hline $\mathbf{R T} * *$ & Compound & $\begin{array}{c}\text { Area } \\
(\%)\end{array}$ & KI* \\
\hline 9.53 & $\alpha$-pinene & 3.32 & 931.1 \\
\hline 10.28 & Camphene & 0.05 & 945.8 \\
\hline 11.71 & $\beta$-pinene & 0.21 & 973.8 \\
\hline 12.49 & $\beta$-minene & 1.68 & 997.9 \\
\hline 13.34 & $\alpha$-phellandrene & 0.04 & 1004.9 \\
\hline 13.95 & $\alpha$-terpinene & 0.07 & 1015.2 \\
\hline 14.44 & P-cimene & 0.80 & 1023.4 \\
\hline 14.77 & D-limonene & 1.50 & 1029.0 \\
\hline 15.04 & Eucalyptol & 15.05 & 1033.6 \\
\hline 15.23 & $\beta$-ocimene & 0.46 & 1036.8 \\
\hline 16.49 & $\gamma$-terpinene & 0.12 & 1058.0 \\
\hline 18.18 & $\alpha$-perpinolene & 0.04 & 1086.5 \\
\hline 19.30 & $\beta$-linallol & 0.46 & 1104.6 \\
\hline 23.83 & Borneol & 0.05 & 1169.1 \\
\hline 24.46 & 4-terpineol & 0.34 & 1178.1 \\
\hline 25.54 & $\alpha$-terpineol & 1.41 & 1193.5 \\
\hline 35.47 & $\alpha$-terpineol acetate & 1.25 & 1344.5 \\
\hline 37.36 & $\alpha$-copaene & 21.96 & 1373.3 \\
\hline 39.82 & Caryophyllene & 2.36 & 1411.3 \\
\hline 40.42 & $\beta$-gurjunene & 0.32 & 1421.5 \\
\hline 42.00 & $\beta$-Caryophyllene & 1.19 & 1447.2 \\
\hline 42.25 & Alloaromadendrene & 0.97 & 1455.3 \\
\hline 43.34 & $\gamma$-muurolene & 2.05 & 1469.0 \\
\hline 43.87 & $\alpha$-curcumene & 0.24 & 1477.7 \\
\hline 44.15 & $\beta$-selinene & 7.73 & 1482.2 \\
\hline 44.60 & $\alpha$-selinene & 6.42 & 1489.6 \\
\hline 44.77 & $\gamma$-muuorelene & 1.43 & 1492.3 \\
\hline 45.06 & Cis- $\alpha$-bisabolene & 0.15 & 1497.1 \\
\hline 45.49 & $\beta$-bisabolene & 0.82 & 1504.3 \\
\hline 45.60 & $\gamma$-cadinene & 0.60 & 1506.1 \\
\hline 46.06 & $\delta$-cadinene & 9.63 & 1514.0 \\
\hline 47.16 & $\alpha$-calacorene & 0.52 & 1532.8 \\
\hline 48.67 & +-Trans-nerolidol & 0.68 & 1558.5 \\
\hline 49.19 & (-)-Spathulenol & 0.10 & 1567.4 \\
\hline 49.45 & Caryophyllene oxide & 1.22 & 1571.8 \\
\hline 50.19 & Globulol & 0.99 & 1584.5 \\
\hline 50.73 & Ledol & 0.19 & 1593.7 \\
\hline 51.04 & Cubenol & 0.65 & 1599.0 \\
\hline 51.53 & Eudesm-7(11)-en-4-ol & 0.67 & 1607.8 \\
\hline 52.16 & Cubenol & 1.60 & 1619.2 \\
\hline 52.96 & $\tau$-cadinol & 0.86 & 1633.6 \\
\hline 53.28 & $\delta$-cadinol & 1.29 & 1639.4 \\
\hline 55.49 & $\alpha$-bisabolol & 0.52 & 1679.4 \\
\hline
\end{tabular}

* KI - Kovats index calculated. **RT - Retention time.

The compound $\alpha$-copaene is a non-oxygenated sesquiterpenic hydrocarbon known for being one of the majority constituents of copaiba oil, used due to its antimicrobial, antiinflammatory, and healing action (Brito et al., 2005).

Eucalyptol is a monoterpene of low toxicity to humans used in the industry, medicine, and for a long time in aromatherapy (Tripathi et al., 2001). In addition to the use for its aroma, eucalyptol has other properties such as antimicrobial, antioxidant (Lee \& Shibamoto, 2001) and bioinseticidal (Sukontason et al., 2004).

Regarding $\alpha$-cadinene and $\delta$-selinene, although they are present in essential oils of some plant species, there are no reports in the literature about the biological potential of these compounds.

Li et al. (1999) conducted a study on Psidium guajava plant through GC-MS and they observed the presence of majority compounds, such as caryophyllene (18.81\%); copaene (11.80\%); and eucalyptol (7.36\%), corroborating with the present study by the presence of the compounds, although with different amounts.

Marques et al. (2008) conducted a phytochemical characterization of the essential oil of $P$. cattleianum collected in the Atlantic Forest of southern Brazil. They used the GC-MS method and the majority constituent found was eucalyptol (16.4\%), among others, corroborating with the finding of the present study. Pino et al. (2004) analyzed the phytochemical composition of $P$. cattleianum collected in Cuba and they identified 18 compounds. The majority compounds were epi- $\alpha$-muurolol $(21.9 \%), \alpha$-cadinol (20\%), epi- $\alpha$-cadinol (16.7\%), and caryophyllene (13.6\%), agreeing with the present study only by the presence of the compounds, since they were not the majority.

When scientific articles are compared, the differences between the phytochemical constituents and their concentrations can result from several factors, such as intraspecific genetic variability, environmental aspects, collection times, growing conditions, soil type, and part of the plant analyzed, which can influence both the content of compounds present in the essential oil and its chemical composition (Alves et al., 2008).

The results presented in Table 2 show that the plant extracts and the essential oil of $P$. cattleianum tested exhibited antimicrobial activity against the microorganisms assessed.

With respect to plant extracts, the ethanolic extract showed the highest antimicrobial activity against microorganisms tested when compared to the aqueous extract regarding the MIC and the MBC, except for the two extracts of P. aeruginosa, P. mirabilis, and B. subtilis which presented the same MIC and MBC values.

In the ethanolic extract, the MIC ranged from 0.78 to $25 \mathrm{mg} / \mathrm{mL}$ for gram-negative bacteria, 0.78 to $3.125 \mathrm{mg} / \mathrm{mL}$ for gram-positive bacteria, and exhibited a MIC of $3.125 \mathrm{mg} / \mathrm{mL}$ for yeast C. albicans. The MBC ranged from 1.56 to $25 \mathrm{mg} / \mathrm{mL}$ for gram-negative and gram-positive bacteria, and exhibited a value of $3.125 \mathrm{mg} / \mathrm{mL}$ for yeast C. albicans.

Due to the aqueous extract, the MIC and the MBC ranged from 6.25 to $50 \mathrm{mg} / \mathrm{mL}$ for gram-negative bacteria, 6.25 to $12.5 \mathrm{mg} / \mathrm{mL}$ for gram-positive bacteria, and presented $\mathrm{MIC}$ and $\mathrm{MBC}$ of $6.25 \mathrm{mg} / \mathrm{mL}$ for yeast C. albicans.

Regarding the antimicrobial activity of the essential oil of $P$. cattleianum, the MIC and the MBC had a value of $200 \mathrm{mg} / \mathrm{mL}$ for all microorganisms tested. 
Table 2. Antimicrobial activity of plant extracts and essential oil of Psidium cattleianum against microorganisms of importance to public health represented by the values of minimum inhibitory concentration (MIC) and minimum bactericidal/ fungicidal concentration (MBC/MFC).

\begin{tabular}{|c|c|c|c|c|}
\hline \multirow{2}{*}{\multicolumn{2}{|c|}{ Microorganisms }} & \multicolumn{3}{|c|}{ MIC/MBC or MFC $(\mathrm{mg} / \mathrm{mL})$} \\
\hline & & Etanolic & Aqueous & Essential Oil \\
\hline \multirow{5}{*}{ Gram - } & P. aeruginosa & $25 / 25$ & $25 / 25$ & $200 / 200$ \\
\hline & $S$. Enteritidis & $25 / 25$ & $50 / 50$ & $200 / 200$ \\
\hline & P. mirabilis & $6.25 / 6.25$ & $6.25 / 6.25$ & $200 / 200$ \\
\hline & K. pneumonia & $0.78 / 1.56$ & $6.25 / 12.5$ & $200 / 200$ \\
\hline & E.coli & $6.25 / 25$ & $12.5 / 50$ & $200 / 200$ \\
\hline \multirow{4}{*}{ Gram + } & E. faecalis & $6.25 / 25$ & $12.5 / 12.5$ & $200 / 200$ \\
\hline & S. epidermidis & $0.78 / 1.56$ & $12.5 / 12.5$ & $200 / 200$ \\
\hline & S. aureus & $3.125 / 3.125$ & $12.5 / 12.5$ & $200 / 200$ \\
\hline & B. subtillis & $6.25 / 6.25$ & $6.25 / 6.25$ & $200 / 200$ \\
\hline Yeast & C. albicans & $3.125 / 3.125$ & $6.25 / 6.25$ & $200 / 200$ \\
\hline
\end{tabular}

There was no microbial growth in the controls and the antimicrobials presented MIC and MBC/MFC less than $6.25 \mathrm{mg} / \mathrm{mL}$. Holetz et al. (2002) established this classification in an article titled "Screening of some plants used in the Brazilian folk medicine for the treatment of infectious diseases", published in Memórias do Instituto Oswaldo Cruz in 2002: extracts with an MIC less than $100 \mu \mathrm{g} / \mathrm{ml}$, the antimicrobial activity is good, from 100 to $500 \mu \mathrm{g} / \mathrm{ml}$ the antimicrobial activity is moderate, from 500 to $1000 \mu \mathrm{g} / \mathrm{ml}$ the antimicrobial activity is weak, and over $1000 \mu \mathrm{g} / \mathrm{ml}$ the extract is considered inactive. Taking this classification into consideration, the ethanolic extract showed weak activity against $K$. pneumonieae and $S$. epidermidis, whereas it was inactive for the other microorganisms. The aqueous extract and the essential oil presented inactive, even though they had inhibited the growth of microorganisms.

Concerning the action of the compounds found in the extracts in bacterial cells, it is known that the flavonoids act in bacterial cells through the formation of complexes between proteins and the cell wall, causing its rupture (Taguri et al., 2004). On the other hand, tannins act in the microorganisms by preventing their growth through the inhibition of the transport of nutrients and the formation of complexes between the tannins and the bacterial cell wall (McSweeney et al., 2001). Finally, the action mechanism of triterpenoids in microorganisms is associated with the disruption of lipophilic compounds of microbial membranes, causing their death (Tepe et al., 2004).

Considering the compounds found in essential oil, the action of $\alpha$-copaene, $\alpha$-cadinene, and $\delta$-selinene in bacterial cells are not reported, it is known that the sesquiterpenes are produced by plants to exert antimicrobial activity (Buchanan et al., 2000) by means of interference in the transduction process (Calixto et al., 2000).

Mojica et al. (2011) assessed the correlation between the antibacterial activity and the components of the essential oil of Calycolpus moritzianus (Myrtaceae) and observed that the components that significantly influenced the antibacterial activity against $S$. aureus, B. subtilis, and
E. faecalis were $\alpha$-copaene and $\alpha$-terpineol, both present in $P$. cattleianum.

With respect to the mode of action of eucalyptol, there are no reports in the literature of its specific action in bacterial cells. However, Turina et al. (2006) reported that owing the high hydrophobicity of monoterpenes, their toxic effects on the bacterial cell membrane result in its expansion, fluidity, and permeability, in addition to causing inhibition of respiration and change in the process of ions transport.

Even though eucalyptol has antimicrobial activity reported, a study assessed the antimicrobial potential of various species of the genus Eucalyptus and no antimicrobial activity was attributed to this compound but to the synergistic capabilities between all the compounds of the essential oil (Cimanga et al., 2002).

The DPPH scavenging index and the half maximal inhibitory concentration $\left(\mathrm{IC}_{50}\right)$ value were determined to assess the antioxidant activity of plant extracts and the essential oil of $P$. cattleianum (Table 3 ). The commercial synthetic antioxidant BHT was used as an equivalence parameter for the antioxidant activity of plant extracts and the essential oil.

The results of the free radicals scavenging percentage of plant extracts and essential oil of $P$. cattleianum, the ethanolic extract exhibited the greatest antioxidant activity, with a scavenging percentage ranging from 94.57 to $94 \%$, followed by the aqueous extract, varying between the 92.62 and $91.58 \%$, and the essential oil, which presented lower antioxidant activity, varying from 16.19 to $4.01 \%$.

Regarding the $\mathrm{IC}_{50}$ values calculated, it should be noted that they were inversely related to the percentage of DPPH scavenging. However, the statistical relationship between the data wasn't the same and the aqueous and ethanolic extracts at the three concentrations tested didn't show significant differences compared to the synthetic antioxidant BHT, as presented in the scavenging percentage. On the other hand, the essential oil showed no statistical difference compared with the control group showing low activity. Although the relationship between the data had 
Table 3. DPPH index (\% scavenging) and $\mathrm{IC}_{50}$ value of the essential oil and plant extracts of Psidium cattleianum at different concentrations tested.

\begin{tabular}{ccc}
\hline Extracts/Oils & SP $\pm \mathbf{S E}^{*}$ & IC $_{\mathbf{5 0}}$ \\
\hline BHT** & $95.84 \pm 0.07 \mathrm{a}$ & $11.51 \pm 0.11 \mathrm{a}$ \\
Etanolic $200 \mathrm{mg} / \mathrm{Ml}$ & $94.57 \pm 0.43 \mathrm{ab}$ & $13.90 \pm 0.53 \mathrm{a}$ \\
Etanolic $150 \mathrm{mg} / \mathrm{mL}$ & $94.29 \pm 0.36 \mathrm{abc}$ & $14.92 \pm 0.42 \mathrm{a}$ \\
Etanolic $100 \mathrm{mg} / \mathrm{mL}$ & $94.00 \pm 0.39 \mathrm{bc}$ & $14.96 \pm 0.53 \mathrm{a}$ \\
Aqueous $200 \mathrm{mg} / \mathrm{mL}$ & $92.62 \pm 0.12 \mathrm{~cd}$ & $17.57 \pm 0.20 \mathrm{a}$ \\
Aqueous $150 \mathrm{mg} / \mathrm{mL}$ & $92.00 \pm 0.20 \mathrm{~d}$ & $18.72 \pm 0.37 \mathrm{a}$ \\
Aqueous $100 \mathrm{mg} / \mathrm{mL}$ & $91.58 \pm 0.16 \mathrm{~d}$ & $19.51 \pm 0.22 \mathrm{a}$ \\
Essentiall Oil $100 \mathrm{mg} / \mathrm{mL}$ & $16.19 \pm 2.33 \mathrm{e}$ & $171.14 \pm 2.56 \mathrm{~b}$ \\
Essentiall Oil $75 \mathrm{mg} / \mathrm{mL}$ & $8.50 \pm 1.23 \mathrm{f}$ & $172.05 \pm 1.48 \mathrm{~b}$ \\
Essentiall Oil $50 \mathrm{mg} / \mathrm{mL}$ & $4.01 \pm 0.80 \mathrm{~g}$ & $183.99 \pm 0.84 \mathrm{~b}$ \\
Control & $0 \pm 0 \mathrm{~h}$ & $191.54 \pm 0 \mathrm{~b}$ \\
\hline
\end{tabular}

*Scavenging percentage \pm Standard error of the mean followed by the same letter in the columns does not differ statistically according to Tukey's test $(\mathrm{p}<0.05)$. ** BHT $=$ Artificial Antioxidant.

not remained the same, the results are evident, since the extracts presented effective antioxidant activity comparable to the synthetic product.

A study conducted by Iha et al. (2008) showed that the ethanolic extract of $P$. guajava had exhibited antioxidant activity, which, according to the authors, was owing the presence of flavonoids, a group of compounds also present in the extracts of the present study. Still, according to the authors, the antioxidant activity of $P$. cattleianum was reported for its fruits, due to the presence of phenolic compounds, especially flavonoids (Medina et al., 2011).

The low antioxidant activity found for the essential oil can be explained as a result from the absence of compounds such as flavonoids, which are one of the main responsible elements for the antioxidant activity of natural products (Podsedek, 2007).

Considering the results obtained throughout the study, it can be mentioned that although the species $P$. cattleianum hasn't been widely studied, it has potential for being used as antioxidant. In addition, it has compounds of industrial interest. This way, the importance of phytochemical studies is highlighted, since they may reveal biological activities of plant extracts and essential oils. Also, it is worth mentioning the importance of initial studies in order to determine the biological activities present in chemical compounds, so that they may be useful as the basis for further studies, such as the isolation of compounds possibly responsible for biological activities. With regard to antioxidant activity, the importance of its determination is relevant, since the compounds used in the formulation of the most various products should present combined actions, such as antimicrobial and antioxidant.

\section{Conclusion}

Regarding the antimicrobial activity, the ethanolic extract exhibited weak activity with respect to bacteria $K$. pneumoniae and S. epidermidis and was inactive to the rest of microorganisms tested. The aqueous extract and the essential oil was inactive. About the antioxidant activity, the essential oil showed no activity, whereas the ethanolic and aqueous extracts exhibited significant values comparable to amount of synthetic antioxidants. The majority compounds of the chemical composition of the essential oil were $\alpha$-copaene, eucalyptol, $\delta$-cadinene, and $\alpha$-selinene, respectively, and the phytochemical tests performed with aqueous and ethanolic plant extracts of $P$. cattleianum revealed the presence of flavonoids, terpenoids, and tannins.

\section{References}

AGRA, M.F., SILVA, K.N., BASÍLIO, I.J.L.D., FRANÇA, P.F. and BARBOSA-FILHO, J.M., 2008. Survey of medicinal plants used in the region Northeast of Brazil. Revista Brasileira de Farmacognosia, vol. 18, no. 3, pp. 472-508. http://dx.doi. org/10.1590/S0102-695X2008000300023.

ALVES, E.G., VINHOLIS, A.H.C., CASEMIRO, L.A., FURTADO, N.A.J.C., SILVA, M.L.A., CUNHA, W.R. and MARTINS, C.H.G., 2008. Estudo comparativo de técnicas de screening para avaliação da atividade antibacteriana de extratos brutos de espécies vegetais e de substâncias puras. Quimica Nova, vol. 31, no. 5, pp. 12241229. http://dx.doi.org/10.1590/S0100-40422008000500052.

AYRES, M.C.C., BRANDÃO, M.S., VIEIRA-JUNIOR, G.M., MENOR, J.C.A.S., SILVA, H.B., SOARES, M.J. and CHAVES, M.H., 2008. Atividade antibacteriana de plantas úteis e constituintes químicos da raiz de Copernicia prunifera. Revista Brasileira de Farmacognosia, vol. 1, pp. 90-97.

BIEGELMEYER, R., ANDRADE, J.M.M., ABOY, A.L., APEL, M.A., DRESCH, R.R., MARIN, R., RASEIRA, M.C. and HENRIQUES, A.T., 2011. Comparative analysis of the chemical composition and antioxidant activity of red (Psidium cattleianum) and yellow (Psidium cattleianum var. lucidum) strawberry guava fruit. Journal of Food Science, vol. 76, no. 7, pp. C991-996. http:// dx.doi.org/10.1111/j.1750-3841.2011.02319.x. PMid:22417549.

BRITO, M.V., MOREIRA, R.J., TAVARES, M.L., CARBALLO, M.C., CARNEIRO, T.X. and SANTOS, A.A., 2005. Copaiba oil effect on urea and creatinine serum levels in rats submitted to kidney ischemia and reperfusion syndrome. Acta Cirurgica Brasileira, vol. 20, no. 3, pp. 243-246. PMid:16033184. 
BUCHANAN, B., GRUISSEM, W. and JONES, R., 2000. Biochemistry and molecular biology of plants. American Society of Plant Physiologists, vol. 10, pp. 1250-1318.

CALIXTO, J.B., BEIRITH, A., FERREIRA, J., SANTOS, A.R.S., CECHINEL FILHO, V. and YUNES, R.A., 2000. Naturally occuring antinociceptive substances from plants. Phytotherapy Research, vol. 14, no. 6, pp. 401-418. http://dx.doi.org/10.1002/10991573(200009)14:6<401::AID-PTR762>3.0.CO;2-H. PMid:10960893.

CEYHAN, N., KESKIN, D. and ZORLU, Z., 2012. Chemical constituents and antimicrobial activity of the leaves of Eucalyptus (Eucaliptus camaldulensis Dehnh.), an endemic plant from West Anatolia. Journal of Pure and Applied Microbiology, vol. 6, pp. 1147-1453.

CIMANGA, K., KAMBU, K., TONA, L., APERS, S., DE BRUYNE, T., HERMANS, N., TOTTÉ, J., PIETERS, L. and VLIETINCK, A.J., 2002. Correlation between chemical composition and antibacterial activity of essential oils of some aromatic medicinal plants growing in the Democratic Republic of Congo. Journal of Ethnopharmacology, vol. 79, no. 2, pp. 213-220. http://dx.doi. org/10.1016/S0378-8741(01)00384-1. PMid:11801384.

COUTO, R.O., VARGAS, A.B., BARA, M T.F. and PAULA, J.R., 2009. Caracterização físico-química do pó das folhas de Eugenia dysenterica (Myrtaceae). Revista Eletrônica de Farmácia, vol. 3, pp. 59-69.

DUFRESNE, C.J. and FARNWORTH, E.R.., 2001. A review of latest research findings on health promotion properties of tea. The Journal of Nutritional Biochemistry, vol. 12, no. 7, pp. 404-421. http://dx.doi.org/10.1016/S0955-2863(01)00155-3. PMid:11448616.

FERREIRA, D.F., 2007. [viewed 22 June 2014]. Sistema Sisvar para análises estatísticas. [online]. Available from: http://www. dex.ufla.br/ danielff/softwares.htm

HOLETZ, F.B., PESSINI, G.L., SANCHES, N.R., CORTEZ, D.A.G., NAKAMURA, C.V. and DIAS FILHO, B.P., 2002. Screening of some plants used in the Brazilian Folk Medicine for the treatment of infectious diseases. Memórias do Instituto Osvaldo Cruz, vol. 97, no. 7, pp. 1027-1031. http://dx.doi.org/10.1590/ S0074-02762002000700017.

IHA, S.M., MIGLIATO, K.F., VELLOSA, J.C.R., SACRAMENTO, L.V.S., PIETRO, R.C.L.R., ISAAC, V.L.B., BRUNETTI, I.L., CORREAA, M.A. and SALGADO, H.R.N., 2008. Estudo fitoquímico de goiaba (Psidium guajava L.) com potencial antioxidante para o desenvolvimento de formulação fitocosmética. Revista Brasileira de Farmacognosia, vol. 18, no. 3, pp. 387-393. http://dx.doi. org/10.1590/S0102-695X2008000300013.

LANDRUM, L.R., 2003. A revision of the Psidium salutare complex (Myrteacea). Journal of the Botanical Research Institute of Texas, vol. 20, pp. 1449-1469.

LEE, K.G. and SHIBAMOTO, T., 2001. Antioxidant activities of volatile componentes isolated from Eucalyptus species. Journal of the Science of Food and Agriculture, vol. 81, no. 15, pp. 15731579. http://dx.doi.org/10.1002/jsfa.980.

LI, J., CHEN, F. and LUO, J., 1999. GC-MS analysis of essential oil from the leaves of Psidum guajava. Zhong Yao Cai, vol. 22, no. 2, pp. 78-80. PMid:12575048.

LUCAS, E.J., BELSHAM, S.R., LUGHADHA, E.M.N., ORLOVICH, D.A., SAKURAGUI, C.M., CHASE, M.W. and WILSON, P.G., 2005. Phylogenetic patterns in the fleshy-fruited Myrtaceae: preliminary molecular evidence. Plant Systematics and
Evolution, vol. 251, no. 1, pp. 35-45. http://dx.doi.org/10.1007/ s00606-004-0164-9.

MARQUES, F.A., WENDLER, E.P., SALES MAIA, B.H.L.N., COFFANI-NUNES, J.V., CAMPANA, J. and GUERRERO JUNIOR, P.G., 2008. Volatile oil of Psidium cattleianum sabine from the Brazilian Atlantic Fores. Journal of Essential Oil Research, vol. 20, no. 6, pp. 519-520. http://dx.doi.org/10.1080 /10412905.2008.9700077.

MCSWEENEY, C.S., PALMER, B., BUNCH, R. and KRAUSE, D.O., 2001. Effect of the tropical forage Calliandra on microbial protein synthesis and ecology in the rumen. Journal of Applied Microbiology, vol. 90, no. 1, pp. 78-88. http://dx.doi.org/10.1046/ j.1365-2672.2001.01220.x. PMid:11155126.

MEDINA, A.L., HAAS, L.I.R., CHAVES, F.C., SALVADOR, M., ZAMBIAZI, R.C., DA SILVA, W.P., NORA, L. and ROMBALDI, C.V., 2011. Aracá (Psidium cattleianum Sabine) fruit extracts with antioxidant and antimicrobial activities and antiproliferative effec on human cancer cells. Food Chemistry, vol. 128, no. 4, pp. 916-922. http://dx.doi.org/10.1016/j.foodchem.2011.03.119.

MOJICA, S.R.D., CAJIAO, P.A.M. and YANEZ, R.X., 2011. Correlacion entre la actividad antibacteriana y los componentes del aceite essencial de Calycolpus moritzianus. Revista de la Facultad de Ciencias Básicas, vol. 9, pp. 9-14.

PINO, J.A., BELlO, A., URQUIOLA, A., AGUERO, J. and MARBOT, R., 2004. Leaf oils of Psidium parvifolium Griseb and Psidium cattleianum Sabine from Cuba. Journal of Essential Oil Research, vol. 15, pp. 187-188. http://dx.doi.org/10.1080/10 412905.2003.9712107.

PINTO, A.C., SILVA, D.H.S., BOLZANI, V.S., LOPES, N.P. and EPIFANIO, R.A., 2002. Produtos naturais: Atualidade, desafios e pespectivas. Quimica Nova, vol. 25, pp. 45-61. http://dx.doi. org/10.1590/S0100-40422002000800009.

PODSEDEK, A., 2007. Natural antioxidants and antioxidant capacity of Brassica vegetables: a review. Swiss Soc. Journal of Food Science and Technology, vol. 40, pp. 1-11.

SACCHETTI, G., MAIETTI, S., MUZZOLI, M., SCAGLIANTI, M., MANFREDINI, S., RADICE, M. and BRUNI, R., 2005. Comparative evaluation of 11 essential oils of different origin as functional antioxidants, antiradicals and antimicrobials in foods. Food Chemistry, vol. 91, no. 4, pp. 621-632. http://dx.doi. org/10.1016/j.foodchem.2004.06.031.

SANTOS, M.S., PETKOWICZ, C.L.O., WOSIACKI, G., NOGUEIRA, A. and CARNEIRO, E.B.B., 2007. Caracterização do suco de aracá vermelho (Psidium cattleianum Sabine) extraído mecanicamente e tratado enzimaticamente. Acta Scientiarum. Agronomy, vol. 29, no. 5, pp. 617-621. http://dx.doi.org/10.4025/ actasciagron.v29i5.737.

SANTURIO, M.J., SANTURIO, D.F., POZZATTI, P., MORAES, C., FRANCHIN, P.R. and ALVES, S.H., 2007. Atividade antimicrobiana dos óleos essenciais de orégano, tomilho e canela frente à sorovares de Salmonella de origem avícola. Ciência Rural, vol. 37, no. 3, pp. 803-808. http://dx.doi.org/10.1590/ S0103-84782007000300031.

SARTORATTO, A., MACHADO, A.L.M., DELARMELINA, C., FIGUEIRA, G.L., DUARTE, M.C.T. and REHDER, V.L.G., 2004. Composition and antimicrobial activity of essential oils from aromatic plants used in Brazil. Brazilian Journal of Microbiology, vol. 35, no. 4, pp. 275-280. http://dx.doi.org/10.1590/S151783822004000300001 . 
SCHERER, R. and GODOY, H.T., 2009. Antioxidant activity index (AAI) by 2,2-diphenyl-1-494 picrylhydrazyl method. Food Chemistry, vol. 112, no. 3, pp. 654-658. http://dx.doi.org/10.1016/j. foodchem.2008.06.026

SILVA, A., PEREZ, S.C.J.G. and PAULA, R.C., 2011. Qualidade fisiológica de sementes de Psidium cattelianum Sabine acondicionadas e armazenadas em diferentes condições. Revista Brasileira de Sementes, vol. 33, no. 2, pp. 197-206. http://dx.doi.org/10.1590/ S0101-31222011000200001.

SIMÕES, C.M.O., SCHENKEL, E.P., GOSMANN, G., MELLO, J.C.P., MENTZ, L.A. and PETROVICK, P.R., 2005. Farmacognosia: da planta ao medicamento. Porto Alegre: Editora da UFSC, no. 5, 1104 p.

SOBRAL, M., PROENÇA, C., SOUZA, M., MAZINE, F. and LUCAS, E., 2010 [viewed 22 June 2014]. Myrtaceae In: JARDIM BOTÂNICO DO RIO DE JANEIRO. Lista de espécies da flora do Brasil [online]. Rio de Janeiro. Available from: Disponível em http://floradobrasil.jbrj.gov.br/2010/FB010262

SUKONTASON, K.L., BOONCHU, N., SUKONTASON, K. and CHOOCHOTE, W., 2004. Effects of eucalyptol on house fly (Diptera: Calliphoridae). Revista do Instituto de Medicina Tropical de Sao Paulo, vol. 46, pp. 97-101. http://dx.doi.org/10.1590/ S0036-46652004000200008. PMid:15141280.

TAGURI, T., TANAKA, T. and KOUNO, I., 2004. Antimicrobial activity of 10 different plant polyphenols against bacteria causing food-borne disease. Biological \& Pharmaceutical Bulletin, vol. 27, no. 12, pp. 1965-1969. http://dx.doi.org/10.1248/bpb.27.1965. PMid:15577214.
TEPE, B., DONMEZ, E., UNLU, M., CANDAN, F., DAFERERA, D., VARDAR-UNLU, G., POLISSIOU, M. and SOKMEN, A., 2004. Antimicrobial and antioxidative activities of the essencial oils and methanol extracts of Salvia cryptanha (Montbret et Aucher ex Benth.) and Salvia multicaulis (Vahl.). Food Chemistry, vol. 84 , no. 4, pp. 519-525. http://dx.doi.org/10.1016/S03088146(03)00267-X.

TRIPATHI, A.K., PRAJAPATI, V., AGGARWAL, K.K. and KUMAR, S., 2001. Toxicity, feeding deterrence and effect of activity of 1,8-Cineole from Artemisia аппиа on propeny production of Tribolium casatanerum (Coleoptera: Tenebrionidae). Journal of Economic Entomology, vol. 94, no. 4, pp. 979-983. http://dx.doi. org/10.1603/0022-0493-94.4.979. PMid:11561861.

TURINA, A.V., NOLAN, M.V., ZYGADLO, J.A. and PERILLO, M.A., 2006. Natural terpenes: self-assembly and membrane partitioning. Biophysical Chemistry, vol. 122, no. 2, pp. 101-113. http://dx.doi.org/10.1016/j.bpc.2006.02.007. PMid:16563603.

VIEGAS JUNIOR, C. BOLZANI, V.S. and BARREIRO, E.J., 2006. Os produtos naturais e a química medicinal moderna. Quimica Nova, vol. 29, no. 2, pp. 326-327. http://dx.doi.org/10.1590/ S0100-40422006000200025.

WEBER, L.D., PINTO, F.G.S., SCUR, M.C., SOUZA, J.G.L., COSTA, W.F. and LEITE, C.W., 2014. Chemical composition and antimicrobial and antioxidant activity of essential oil and various plant extracts from Prunus myrtifolia. African Journal of Agricultural Research, vol. 9, no. 9, pp. 846-853. http://dx.doi. org/10.5897/AJAR2013.8260. 